\title{
Analisis Penggunaan E-Filing oleh Wajib Pajak Orang Pribadi dengan Menggunakan UTAUT 2
}

\author{
Ni Putu Novia Triana Dewi ${ }^{1}$ \\ Fakultas Ekonomi dan Bisnis \\ Universitas Udayana, Indonesia
}

\author{
Putu Ery Setiawan ${ }^{2}$ \\ Fakultas Ekonomi dan Bisnis \\ Universitas Udayana, Indonesia
}

\begin{abstract}
Surel : triananovi2@gmail.com
ABSTRAK

Tujuan penelitian ini adalah untuk meneliti faktor-faktor yang mempengaruhi penggunaan e-Filing oleh wajib pajak orang pribadi dengan menggunakan Unified Theory Of Acceptance And Use Of Technology 2 (UTAUT 2). Penelitian ini dilakukan pada wajib pajak orang pribadi pengguna e-Filing pada tahun 2018 yang terdaftar di Kantor Pelayanan Pajak Pratama Tabanan. Metode yang digunakan non probability sampling dengan teknik accidental sampling dan sampel sebanyak 100 orang. Pengumpulan data dilakukan dengan penyebaran kuesioner. Teknik analisis yang digunakan adalah regresi linear berganda. Berdasarkan hasil analisis diketahui bahwa ekspektasi kinerja, faktor sosial, kondisi yang memfasilitasi dan motivasi hedonisme tidak berpengaruh pada penggunaan e-Filing oleh wajib pajak orang pribadi. ekspektasi usaha, nilai harga dan kebiasaan berpengaruh positif pada penggunaan $e$-Filing oleh wajib pajak orang pribadi di KPP Pratama Tabanan.
\end{abstract}

Kata Kunci: $\quad$ E-Filing; Wajib Pajak Orang Pribadi; UTAUT 2.

\section{Analysis of the Use of E-Filing by Individual Taxpayers Using UTAUT 2}

\section{ABSTRACT}

The purpose of this study is to find out the factors affecting personal taxpayers to use e-Filing based on Unified Theory of Acceptance and Use of Technology 2 (UTAUT 2). This research conducted on individual taxpayers of e-filing users in 2018 registered at the Tabanan Primary Tax Service. The method used is non-probability sampling with accidental sampling technique. Data collected by distributing questionnaires to 100 individual taxpayers. The analysis technique used is multiple linear regression. Based on the results of the analysis that the performance expectations, sosial factor, facilitating condition and hedonic motivation have no effect on the use of e-Filing by individual taxpayers, effort expectation, price value and habit have a positive effect on the use of e-Filing by individual taxpayers in Tabanan Primary Tax Service.

Keywords: $\quad$ E-Filing, Personal Taxpayers, UTAUT 2.

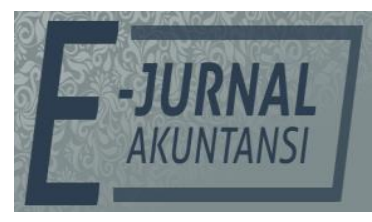

e-ISSN 2302-8556

Vol. 30 No. 12

Denpasar, Desember 2020

Hal. 3081-3095

DOI:

10.24843/EJA.2020.v30.i12.p07

PENGUTIPAN:

Dewi, N.P.N.T. \& Setiawan, P.E. (2020). Analisis

Penggunaan E-Filing oleh

Wajib Pajak Orang Pribadi dengan Menggunakan

UTAUT 2. E-Iurnal

Akuntansi, 30(12), 3081-3095

RIWAYAT ARTIKEL:

Artikel Masuk:

28 Januari 2020

Artikel Diterima:

9 Juni 2020

Artikel dapat diakses : https://ojs.unud.ac.id/index.php/Akuntansi/index 


\section{PENDAHULUAN}

Sistem $e$-Filing saat ini sudah digunakan oleh sebagian wajib pajak, namun belum semua wajib pajak menggunakan e-Filing untuk melaporkan SPT. Sebagian wajib pajak masih enggan melaporkan SPT melalui sistem e-Filing dan lebih memilih untuk datang ke Kantor Pelayan Pajak (KPP) langsung. Data dari Kementerian Keuangan Republik Indonesia menunjukkan pada tahun 2017 sebanyak 6.733 .107 wajib pajak orang pribadi (WPOP) melaporkan SPT mereka secara elektronik. Tahun 2018 jumlahnya menjadi meningkat sebanyak 8.213.098 WPOP dari jumlah 10.051.101 SPT Tahunan WPOP yang masuk. Hal tersebut mengindikasikan bahwa terdapat pertumbuhan sebesar 21,9 persen pelaporan SPT melalui e-Filing dari tahun 2017 ke tahun 2018. Disisi lain angka tersebut menunjukkan bahwa pada tahun 2018 masih terdapat sekitar 18,3 persen WPOP yang tidak melaporkan SPT mereka melalui e-Filing.

Direktorat Jendral Pajak (DJP) memang masih memperbolehkan beberapa wajib pajak orang pribadi untuk melaporkan kewajiban perpajakan mereka melalui pos atau datang langsung ke kantor pelayanan pajak, namun disisi lain DJP masih terus gencar dalam mendorong wajib pajak agar menggunakan $e$ Filing dan terus berusaha meningkatkan infrastruktur sistem e-Filing agar wajib pajak tertarik untuk beralih menggunakan layanan sistem $e$-Filing.

Penelitian ini mengacu pada penelitian yang dilakukan oleh Purnaningsih \& Noviari (2019). Penelitian tersebut meneliti mengenai minat penggunaan $e-$ Filing oleh WPOP di Kantor Pelayanan Pajak (KPP) Pratama Gianyar dengan model Unified Theory of Acceptance and Use of Technology (UTAUT). Pada penelitian ini peneliti memilih meneliti penggunaan e-Filing di KPP Pratama Tabanan. Wilayah KPP Pratama Tabanan terdiri dari Kabupaten Tabanan dan Jembrana yang mencakup daerah perkotaan dan pedesaan.

Penggunaan e-Filing sangat membutuhkan jaringan internet yang stabil. Sedangkan belum semua wilayah kerja KPP Pratama Tabanan memiliki jaringan internet yang baik. Berdasarkan hambatan tersebut, peneliti merasa perlu melakukan penelitian terkait dengan penggunaan e-Filing di KPP Pratama Tabanan. Data pelaporan SPT oleh wajib pajak orang pribadi yang terdaftar di KPP Pratama Tabanan disajikan pada Tabel 1, berikut ini.

Tabel 1. Pelaporan SPT Wajib Pajak Orang Pribadi di KPP Pratama Tabanan

\begin{tabular}{lrccrr}
\hline Tahun & $\begin{array}{c}\text { WPOP } \\
\text { terdaftar } \\
\text { (orang) }\end{array}$ & $\begin{array}{c}\text { Pelaporan } \\
\text { SPT melalui } \\
\text { e-Filing }\end{array}$ & $\begin{array}{c}\text { Pelaporan } \\
\text { SPT secara } \\
\text { langsung }\end{array}$ & $\begin{array}{c}\text { Jumlah SPT } \\
\text { Masuk }\end{array}$ & $\begin{array}{c}\text { Persentase } \\
\text { Pelaporan } \\
\text { SPT Secara } \\
\text { Langsung } \\
(\%)\end{array}$ \\
\hline 2016 & 96.531 & 36.930 & 8.928 & 45.858 & 19,46 \\
2017 & 104.665 & 37.919 & 5.006 & 42.925 & 11,66 \\
2018 & 113.429 & 38.704 & 5.367 & 44.071 & 12,17 \\
\hline
\end{tabular}

Sumber : KPP Pratama Tabanan, 2019

Data dari Kantor Pelayanan Pajak (KPP) Pratama Tabanan menunjukkan Pelaporan SPT melalui e-Filing dari tahun 2016 sampai 2018 terus mengalami peningkatan setiap tahunnya. Data pada Tabel 1, tersebut menunjukkan bahwa masih terdapat wajib pajak orang pribadi yang melaporkan SPT mereka secara langsung. Pelaporan SPT secara langsung adalah pelaporan SPT yang dilakukan 
wajib pajak dengan datang langsung ke KPP. Persentase pelaporan SPT secara langsung dari tahun 2016 ke 2017 mengalami penurunan dari 19,46 persen menjadi 11,66 persen, namun pada tahun 2018 persentase pelaporan SPT secara langsung mengalami peningkatan menjadi 12,17 persen.

Teori Unified Theory of Acceptance and Use of Technology (UTAUT) merupakan suatu teori yang digunakan untuk mendefinisikan perilaku pengguna terhadap teknologi informasi. Pada UTAUT ini terdapat empat faktor utama yang menjelaskan perilaku pengguna yaitu, ekspektasi kinerja, ekspektasi usaha, faktor sosial dan kondisi yang memfasilitasi. Empat faktor tersebut merupakan hasil gabungan dari delapan teori-teori sebelumnya yang digunakan untuk menjelaskan perilaku pengguna terhadap teknologi informasi yang meliputi Theory of Reasoned Action (TRA), Technology Acceptance Model (TAM), Motivational Model (MM), Theory of Planned Behavior (TPB), combinedTAM and TPB, Model of PC utilization (MPTU), Innovation Diffusion Theory (IDT), dan Sosial Cognitive Theory (SCT). Teori UTAUT ini terbukti lebih berhasil dibandingkan kedelapan teori sebelumnya dalam menjelaskan minat penggunaan teknologi informasi (Hartono \& Meiranto, 2015).

Penelitian-penelitian sebelumnya yang sejenis yang menggunakan UTAUT menunjukkan hasil yang inkonsisten pada masing-masing indikator yang dijadikan variabel penelitian. Penelitian yang dilakukan oleh Nugroho et al. (2018) menyatakan bahwa ekspektasi kinerja dan pengaruh sosial berpengaruh positif terhadap penggunaan e-billing, sedangkan ekspektasi usaha dan kondisi yang memfasilitasi tidak berpengaruh signifikan terhadap penggunaan sistem e-billing. Hasil penelitian lainnya dari Wulandari \& Yadnyana (2016) menyatakan bahwa ekspektasi kinerja, ekspektasi usaha, faktor sosial dan kondisi yang memfasilitasi mempunyai pengaruh positif yang signifikan pada minat penggunaan e-Filing di Kota Denpasar.

Perkembangan teknologi semakin pesat sehingga menjadi salah satu alasan diperlukannya pengembangan baru dari model UTAUT dan hasil dari pengembangan model UTAUT ini dinamakan model UTAUT 2. Model UTAUT 2 terdiri atas tiga konstruk tambahan yaitu motivasi hedonisme, nilai harga, dan kebiasaan (Auliya, 2018). Penelitian-penelitian sebelumnya yang menggunakan UTAUT 2 untuk menjelaskan minat dan perilaku pengguna terhadap teknologi diantaranya adalah penelitian yang dilakukan oleh Putri \& Suardikha (2019). Hasil penelitian tersebut menunjukkan bahwa ekspektasi usaha, motivasi hedonisme, nilai harga dan kebiasaan berpengaruh positif terhadap minat penggunaan teknologi serta variabel kebiasaan dan minat penggunaan berpengaruh positif terhadap penggunaan teknologi, sedangkan ekspektasi kinerja, faktor sosial dan kondisi yang memfasilitasi tidak mempengaruhi minat penggunaan teknologi (Putri \& Suardikha, 2019). Hasil penelitian dari Pertiwi \& Ariyanto (2017) menyatakan bahwa ekspektasi kinerja berpengaruh positif terhadap minat penggunaan mobile banking. Kebiasaan dan minat penggunaan berpengaruh positif pada perilaku penggunaan mobile banking, sedangkan ekspektasi kinerja, motivasi hedonisme, nilai harga dan kondisi yang memfasilitasi tidak berpengaruh pada perilaku penggunaan mobile banking. 
Ekspektasi kinerja merupakan manfaat yang diyakini individu dapat diperolehnya apabila menggunakan suatu teknologi yang akan membantu pengguna untuk membuat performa kinerja mereka menjadi lebih meningkat. Keefektifan sistem informasi dalam memenuhi kebutuhan pengguna dapat meningkatkan kepuasan pengguna terhadap sistem informasi tersebut. Keefektifan sistem informasi ini dapat dilihat dari kebutuhan atau tujuan yang dimiliki pengguna dapat tercapai sesuai harapan atau target yang diinginkan.

Penelitian yang dilakukan oleh Yadnyana et al. (2017), Annisa \& Soewarno (2019), Wulandari \& Yadnyana (2016) serta Lu \& Nguyen (2016) menyatakan bahwa ekspektasi kinerja berpengaruh positif terhadap minat penggunaan $e$ Filing. Hasil tersebut juga didukung oleh hasil penelitian yang dilakukan oleh Nugroho et al. (2018) yang menyatakan bahwa ekspektasi kinerja berpengaruh positif terhadap penerimaan sistem. Jadi berdasarkan penjelasan tersebut dapat disimpulkan bahwa wajib pajak akan menggunakan sistem e-Filing ketika wajib pajak percaya sistem tersebut akan membuat aktivitas pelaporan SPT menjadi lebih maksimal. Berdasarkan penjelasan tersebut, maka hipotesis pertama pada penelitian ini adalah sebagai berikut.

$\mathrm{H}_{1}$ : Ekspektasi kinerja berpengaruh positif pada penggunaan e-Filing.

Ekspektasi usaha adalah suatu kondisi dimana individu tersebut merasa teknologi yang digunakan mudah untuk dipahami dan digunakan. Hal ini berkaitan dengan keefisienan yang dirasakan oleh pengguna dalam menggunakan teknologi untuk melakukan aktivitasnya. Penggunaan e-Filing adalah solusi untuk mempermudah wajib pajak dalam melaporkan Surat Pemberitahuan (SPT) sehingga dapat mempercepat kegiatan pelaporan pajak (Hadisantoso et al., 2019). Penelitian yang dilakukan oleh Lu \& Nguyen (2016) menyimpulkan bahwa ekspektasi usaha berpengaruh positif pada minat penggunaan e-Filing oleh wajib pajak. Berdasarkan penjelasan tersebut, maka hipotesis kedua penelitian ini adalah sebagai berikut.

$\mathrm{H}_{2}$ : Ekspektasi usaha berpengaruh positif pada penggunaan e-Filing.

Faktor sosial adalah pengaruh orang lain atau lingkungan sekitar yang membuat seseorang memakai suatu sistem teknologi. Dalam penggunaan $e$-Filing lingkungan yang paling berperan adalah pihak Direktorat Jenderal Pajak (DJP). Peran DJP sangat dibutuhkan untuk memperkenalkan sistem e-Filing kepada wajib pajak misalnya melalui kegiatan sosialisai tentang ajakan menggunakan $e^{-}$ Filing atau dengan memberikan pelayanan konsultasi kepada wajib pajak yang belum paham mengenai $e$-Filing. Penelitian yang dilakukan oleh Mangoting et al. (2019), Olaoye \& Atilola (2018), Kimea et al. (2019), Mongwaketse (2015), Syaninditha \& Setiawan (2017), Zaidi (2017) serta Lu \& Nguyen (2016) menyatakan bahwa faktor sosial berpengaruh positif terhadap minat perilaku wajib pajak dalam penggunaan e-Filing. Berdasarkan penjelasan tersebut, maka hipotesis ketiga penelitian ini adalah sebagai berikut.

$\mathrm{H}_{3}$ : Faktor sosial berpengaruh positif pada penggunaan $e$-Filing.

Wajib pajak minimal harus mempunyai fasilitas-fasilitas yang mendukung mereka untuk melaporkan kewajiban perpajakan secara online. Misalnya wajib pajak minimal harus berada pada wilayah yang mempunyai akses internet dan mempunyai sebuah komputer atau laptop agar dapat melaporkan Surat Pemberitahuan (SPT) mereka secara online melalui sistem $e$-Filing. 
Faktor dari internal meliputi kondisi kesiapan seorang individu terkait dengan pengetahuan ataupun pengalamam yang mereka punya untuk menerapkan suatu teknologi tersebut. Hasil penelitian Sichone \& Milano (2017), Rakhmawati (2020), Syaninditha \& Setiawan (2017), Alraja (2016) menyatakan bahwa kondisi yang memfasilitas berpengaruh secara positif terhadap penggunaan e-Filing. Penelitian Wulandari \& Yadnyana (2016) juga mendukung hasil penelitian sebelumnya. Berdasarkan penjelasan tersebut, maka hipotesis keempat penelitian ini adalah sebagai berikut.

$\mathrm{H}_{4}$ : Kondisi yang memfasilitasi berpengaruh positif pada penggunaan e-Filing.

Rasa kesenangan dan kebanggaan yang didapatkan oleh wajib pajak dalam melaporkan SPT mereka melalui e-Filing dapat mempengaruhi wajib pajak untuk terus menggunakan e-Filing dalam melaporkan SPT. Beberapa penelitian yang dilakukan sebelumnya terkait dengan penerimaan penggunaan teknologi, seperti penelitian yang dilakukan oleh Lu \& Nguyen (2016) menemukan bahwa motivasi hedonisme mempengaruhi penerimaan dan penggunaan teknologi oleh pengguna. Penelitian oleh Putri \& Suardikha (2019) juga menyatakan hal yang sama. Berdasarkan penjelasan diatas, maka rumusan hipotesis kelima adalah sebagai berikut.

$\mathrm{H}_{5}$ : Motivasi hedonisme berpengaruh positif pada penggunaan e-Filing.

Biaya penggunaan e-Filing yang sebanding dengan manfaat dan kemudahan yang didapat oleh wajib pajak akan membuat wajib pajak lebih memilih untuk menggunakan e-Filing tersebut sebagai sarana pelaporan kewajiban perpajakan mereka. Rahman \& Dewantara (2017) menunjukkan bahwa nilai harga berpengaruh terhadap penggunaan teknologi oleh pengguna. Hasil tersebut juga menunjukkan hal yang sama dengan penelitian yang dilakukan oleh Putri \& Suardikha (2019). Berdasarkan penjelasan tersebut, maka hipotesis keenam penelitian sebagai berikut.

$\mathrm{H}_{6}$ : Nilai harga berpengaruh positif pada penggunaan e-Filing.

Kebiasaan adalah tingkah laku seseorang yang berperilaku secara otomatis karena pembelajaran sebelumnya dan dilakukan secara berulangulang Wajib pajak yang terbiasa menggunakan suatu teknologi dalam pekerjaan sehari-harinya akan lebih memilih melaporkan kewajiban perpajakan mereka melalui e-Filing karena terbiasa dengan hal-hal yang praktis. Penelitian Sutanto et al. (2018) menunjukkan bahwa terdapat pengaruh yang signifikan dari kebiasaan konsumen pada penggunaan teknologi. Hasil tersebut juga konsisten dengan penelitian Pertiwi \& Ariyanto (2017), Putri \& Suardikha (2019), Veeramootoo, Nunko, \& Dwivedi (2018). Berdasarkan penjelasan tersebut, maka hipotesis ketujuh penelitian sebagai berikut.

$\mathrm{H}_{7}$ : Kebiasaan berpengaruh positif pada penggunaan e-Filing.

\section{METODE PENELITIAN}

Penelitian ini merupakan jenis penelitian yang menggunakan metode penelitian kuantitatif yang bersifat asosiatif. Obyek penelitian ini adalah pengaruh ekspektasi kinerja, ekspektasi usaha, faktor sosial, kondisi yang memfasilitasi, motivasi hedonisme, nilai harga dan kebiasaan pada penggunaan e-Filing oleh wajib pajak orang pribadi yang terdaftar di Kantor Pelayanan Pajak Pratama Tabanan. 
Metode pengambilan sampel yang digunakan dalam penelitian ini adalah metode nonprobability sampling dengan teknik accidental sampling. Teknik accidental sampling merupakan teknik sampling dengan datang langsung ke lokasi penelitian dan mengambil responden secara kebetulan, siapapun yang ditemui dan dilihat cocok dengan karakteristik sample penelitian dijadikan sebagai sumber data. Populasi pada penelitian ini adalah seluruh wajib pajak orang pribadi yang terdaftar pada Kantor Pelayanan Pajak Pratama Tabanan yang melaporkan SPT mereka melalui e-Filing tahun 2018 yaitu berjumlah 38.704 dengan sample sebanyak 100 orang. Metode pengumpulan data yang digunakan adalah metode survey berupa kuesioner. Teknik analisis data yang digunakan dalam penelitian ini adalah regresi linear berganda.

\section{HASIL DAN PEMBAHASAN}

Pengumpulan data dalam penelitian ini dilakukan dengan penyebaran 100 kuesioner kepada wajib pajak orang pribadi yang terdaftar di KPP Pratama Tabanan yang menggunakan e-Filing dan menghasilkan respons rate dan usable respons rate sebesar $100 \%$. Rincian karakteristik responden dijabarkan pada Tabel 2, sebagai berikut.

\section{Tabel 2. Rincian Karakteristik Responden}

\begin{tabular}{|c|c|c|}
\hline Keterangan & Jumlah & Persentase \\
\hline \multicolumn{3}{|l|}{ Jenis Kelamin } \\
\hline Laki-laki & 45 & 45 \\
\hline \multirow[t]{2}{*}{ Perempuan } & $\underline{55}$ & $\underline{55}$ \\
\hline & 100 & 100 \\
\hline \multicolumn{3}{|l|}{ Pekerjaan } \\
\hline Pegawai Swasta & 62 & 62 \\
\hline Pegawai Negeri & 19 & 19 \\
\hline Wiraswasta & 9 & 9 \\
\hline \multirow[t]{2}{*}{ Lainnya } & $\underline{10}$ & $\underline{10}$ \\
\hline & 100 & 100 \\
\hline \multicolumn{3}{|l|}{ Menggunakan $e$-Filing sejak } \\
\hline$\leq 2013$ & 3 & 3 \\
\hline 2014 & 1 & 1 \\
\hline 2015 & 4 & 4 \\
\hline 2016 & 11 & 11 \\
\hline 2017 & 24 & 24 \\
\hline \multirow[t]{2}{*}{2018} & $\underline{57}$ & $\underline{57}$ \\
\hline & 100 & 100 \\
\hline
\end{tabular}

Sumber : Data Penelitian, 2019

Tabel 2, menunjukkan rincian karakteristik responden penelitian. Responden penelitian sebagian besar adalah perempuan dengan jumlah lima puluh lima orang. Sedangkan responden yang berjenis kelamin laki-laki berjumlah empat puluh lima orang. Responden penelitian sebagian besar berprofesi sebagai pegawai swasta dengan jumlah enam puluh dua orang, pegawai negeri berjumlah sembilan belas orang, wiraswasta berjumlah sembilan orang dan lainnya berjumlah sepuluh orang. Adapun yang dimaksud pekerjaan lainnya dari responden penelitian ini diantaranya adalah notaris, konsultan pajak serta pensiunan PNS/ BUMN. Responden penelitian sebagian besar baru 
menerapkan e-Filing sejak tahun 2018 sebanyak lima puluh tujuh orang, tahun 2017 sebanyak dua puluh empat orang, tahun 2016 sebanyak sebelas orang, tahun 2015 sebanyak empat orang, tahun 2014 sebanyak satu orang dan tahun 2013 atau sebelumnya sebanyak tiga orang.

Tabel 3. Hasil Uji Validitas

\begin{tabular}{|c|c|c|}
\hline Variabel & Instrumen & $\begin{array}{c}\text { Pearson } \\
\text { Correlation }\end{array}$ \\
\hline \multirow[t]{3}{*}{ Ekspektasi Kinerja $\left(\mathrm{X}_{1}\right)$} & $\mathrm{X}_{1.1}$ & 0,913 \\
\hline & $\mathrm{X}_{1.2}$ & 0,977 \\
\hline & $\mathrm{X}_{1.3}$ & 0,972 \\
\hline \multirow[t]{3}{*}{ Ekspektasi Usaha $\left(\mathrm{X}_{2}\right)$} & $\mathrm{X}_{2.1}$ & 0,893 \\
\hline & $\mathrm{X}_{2.2}$ & 0,934 \\
\hline & $X_{2.3}$ & 0,946 \\
\hline \multirow[t]{4}{*}{ Faktor Sosial $\left(X_{3}\right)$} & $X_{3.1}$ & 0,656 \\
\hline & $X_{3.2}$ & 0,778 \\
\hline & $X_{3.3}$ & 0,841 \\
\hline & $X_{3.4}$ & 0,760 \\
\hline \multirow[t]{3}{*}{ Kondisi yang Memfasilitasi $\left(\mathrm{X}_{4}\right)$} & $X_{4.1}$ & 0,891 \\
\hline & $\mathrm{X}_{4.2}$ & 0,891 \\
\hline & $\mathrm{X}_{4.3}$ & 0,777 \\
\hline \multirow[t]{3}{*}{ Motivasi Hedonisme $\left(\mathrm{X}_{5}\right)$} & $X_{5.1}$ & 0,929 \\
\hline & $X_{5.2}$ & 0,963 \\
\hline & $X_{5.3}$ & 0,963 \\
\hline \multirow[t]{3}{*}{ Nilai Harga $\left(\mathrm{X}_{6}\right)$} & $X_{6.1}$ & 0,904 \\
\hline & $X_{6.2}$ & 0,898 \\
\hline & $X_{6.3}$ & 0,811 \\
\hline \multirow[t]{3}{*}{ Kebiasaan $\left(X_{7}\right)$} & $X_{7.1}$ & 0,876 \\
\hline & $X_{7.2}$ & 0,917 \\
\hline & $X_{7.3}$ & 0,850 \\
\hline \multirow[t]{3}{*}{ Peenggunaan $e$-Filing $\left(\mathrm{Y}_{1}\right)$} & $Y_{1.1}$ & 0,916 \\
\hline & $\mathrm{Y}_{1.2}$ & 0,887 \\
\hline & $\mathrm{Y}_{1.3}$ & 0,801 \\
\hline
\end{tabular}

Sumber: Data Penelitian, 2019

Tabel 3, menunjukkan bahwa koefisien korelasi dari seluruh instrumen lebih besar dari 0,3. Koefisien korelasi yang lebih besar dari 0,3 berarti instrumen penelitian valid dan layak digunakan dalam penelitian.

Tabel 4. Hasil Uji Reliabilitas

\begin{tabular}{lc}
\hline \multicolumn{1}{c}{ Variabel } & Cronbach's Alpha \\
\hline Ekspektasi Kinerja $\left(\mathrm{X}_{1}\right)$ & 0,949 \\
Ekspektasi Usaha $\left(\mathrm{X}_{2}\right)$ & 0,913 \\
Faktor Sosial $\left(\mathrm{X}_{3}\right)$ & 0,758 \\
Kondisi yang Memfasilitasi $\left(\mathrm{X}_{4}\right)$ & 0,814 \\
Motivasi Hedonisme $\left(\mathrm{X}_{5}\right)$ & 0,948 \\
Nilai Harga $\left(\mathrm{X}_{6}\right)$ & 0,828 \\
Kebiasaan $\left(\mathrm{X}_{7}\right)$ & 0,855 \\
Peenggunaan e-Filing $\left(\mathrm{Y}_{1}\right)$ & 0,838 \\
\hline
\end{tabular}

Sumber: Data Penelitian, 2019

Tabel 4, menunjukkan bahwa Cronbach's Alpha dari seluruh variabel lebih besar dari 0,70 maka dapat disimpulkan bahwa instrument kuesioner tersebut reliabel. 
Uji normalitas bertujuan untuk mengetahui apakah dalam sebuah model regresi, variabel terikat, variabel bebas atau keduanya mempunyai distribusi yang normal atau tidak. Model regresi penelitian dikatakan normal apabila Asymp. Sig (2-tailed) lebih besar dari level signifikan yang dipakai $(0,05)$. Hasil uji normalitas penelitian ini disajikan pada Tabel 5, berikut ini.

\section{Tabel 5. Hasil Uji Normalitas}

\begin{tabular}{lll}
\hline Model Regresi & $\mathrm{N}$ & Asymp. Sig (2-tailed) \\
\hline Model 1 & 100 & 0,200 \\
\hline
\end{tabular}

Sumber: Data Penelitian, 2019

Tabel 5, Menunjukkan bahwa Asymp. Sig (2-tailed) untuk persamaan model regresi penelitian ini adalah 0,200 dimana angka tersebut lebih besar dari 0,05. Hal ini berarti model regresi tersebut berdistribusi normal.

Uji multikolonieritas digunakan untuk menguji apakah dalam model regresi ditemukan adanya korelasi antar variabel bebas. Jika nilai tolerance lebih besar dari 0,1 (10 persen) atau VIF kurang dari 10, maka dikatakan tidak ada multikolonieritas. Hasil uji multikolonieritas disajikan pada Tabel 6, sebagai berikut.

Tabel 6. Hasil Uji Multikolonieritas

\begin{tabular}{lcc}
\hline \multicolumn{1}{c}{ Variabel } & Tolerance & VIF \\
\hline Ekspektasi Kinerja $\left(\mathrm{X}_{1}\right)$ & 0,351 & 2,850 \\
Ekspektasi Usaha $\left(\mathrm{X}_{2}\right)$ & 0,405 & 2,467 \\
Faktor Sosial $\left(\mathrm{X}_{3}\right)$ & 0,581 & 1,721 \\
Kondisi yang Memfasilitasi $\left(\mathrm{X}_{4}\right)$ & 0,455 & 2,199 \\
Motivasi Hedonisme $\left(\mathrm{X}_{5}\right)$ & 0,328 & 3,053 \\
Nilai Harga $\left(\mathrm{X}_{6}\right)$ & 0,466 & 2,146 \\
Kebiasaan $\left(\mathrm{X}_{7}\right)$ & 0,338 & 2,960 \\
\hline
\end{tabular}

Sumber: Data Penelitian, 2019

Tabel 6, menunjukkan bahwa nilai tolerance masing-masing variabel lebih besar dari 0,1 dan nilai VIF lebih kecil dari 10, sehingga dapat dinyatakan bahwa model regresi pada penelitian ini tidak terjadi gejala multikolonieritas.

Uji heteroskedastisitas bertujuan untuk menguji apakah pada model regresi terjadi gejala ketidaksamaan varians dari residual pengamatan ke pengamatan lain. Model regresi dapat dikatakan bebas dari gejala heteroskedastisitas jika tingkat signifikansi lebih dari 0,05. Hasil uji heteroskedastisitas disajikan pada Tabel 7, sebagai berikut.

Tabel 7. Hasil Uji Heteroskedastisitas

\begin{tabular}{lc}
\hline \multicolumn{1}{c}{ Variabel } & Sig \\
\hline Ekspektasi Kinerja $\left(\mathrm{X}_{1}\right)$ & 0,129 \\
Ekspektasi Usaha $\left(\mathrm{X}_{2}\right)$ & 0,116 \\
Faktor Sosial $\left(\mathrm{X}_{3}\right)$ & 0,777 \\
Kondisi yang Memfasilitasi $\left(\mathrm{X}_{4}\right)$ & 0,277 \\
Motivasi Hedonisme $\left(\mathrm{X}_{5}\right)$ & 0,799 \\
Nilai Harga $\left(\mathrm{X}_{6}\right)$ & 0,082 \\
Kebiasaan $\left(\mathrm{X}_{7}\right)$ & 0,689 \\
\hline
\end{tabular}

Sumber: Data Penelitian, 2019

Tabel 7, Menunjukkan bahwa nilai signifikan masing-masing variabel lebih besar dari 0,05 yang berarti model regresi pada penelitian ini bebas dari gejala heteroskedastisitas. 
Analisis regresi linear berganda digunakan untuk mengetahui pengaruh variabel bebas pada variabel terikat. Analisis dalam penelitian ini dilakukan dengan menggunakan bantuan program SPSS versi 25 for windows. Hasil analisis regresi linear berganda disajikan pada Tabel 8, sebagai berikut.

\section{Tabel 8. Hasil Regresi Linear Berganda}

\begin{tabular}{|c|c|c|c|c|c|}
\hline \multirow{2}{*}{ Model } & \multicolumn{2}{|c|}{$\begin{array}{l}\text { Unstandardized } \\
\text { Coefficients }\end{array}$} & \multirow{2}{*}{$\begin{array}{c}\begin{array}{c}\text { Standardized } \\
\text { Coefficients }\end{array} \\
\text { Beta }\end{array}$} & \multirow{2}{*}{$\mathrm{T}$} & \multirow{2}{*}{ Sig. } \\
\hline & B & $\begin{array}{l}\text { Std. } \\
\text { Error }\end{array}$ & & & \\
\hline (Constant) & 1,890 & 1,812 & & 1,043 & 0,300 \\
\hline Ekspektasi Kinerja & $-0,067$ & 0,176 & $-0,048$ & $-0,381$ & 0,704 \\
\hline Ekspektasi Usaha & 0,313 & 0,127 & 0,288 & 2,460 & 0,016 \\
\hline Faktor Sosial & $-0,197$ & 0,107 & $-0,180$ & $-1,844$ & 0,068 \\
\hline Kondisi yang & $-0,001$ & 0,148 & 0,000 & $-0,004$ & 0,997 \\
\hline \multicolumn{6}{|l|}{ Memfasilitasi } \\
\hline Motivasi Hedonisme & 0,102 & 0,164 & 0,081 & 0,621 & 0,536 \\
\hline Nilai Harga & 0,406 & 0,142 & 0,312 & 2,859 & 0,005 \\
\hline Kebiasaan & 0 ,et 335 & 0,138 & 0,311 & 2,428 & 0,017 \\
\hline Adjusted $R^{2}$ & & & & & 0,451 \\
\hline F Hitung & & & & & 12,629 \\
\hline Sig. $f$ & & & & & 0,000 \\
\hline
\end{tabular}

Sumber: Data Penelitian, 2019

Model summary besarnya Adjusted $R^{2}$ untuk variabel terikat penggunaan eFiling adalah sebesar 0,451. Hal tersebut menunjukkan bahwa variasi penggunaan e-Filing dapat dijelaskan oleh variabel ekspektasi kinerja, ekspektasi usaha, faktor sosial, kondisi yang memfasilitasi, motivasi hedonisme, nilai harga dan kebiasaan sebesar 45,1 persen, sedangkan sisanya sebesar 54,9 persen dijelaskan oleh faktor-faktor lain.

F hitung untuk variabel terikat penggunaan e-Filing adalah 12,629 dengan signifikansi $\mathrm{F}=0,000$ yang lebih kecil dari $\alpha=0,05$. Hal tersebut berarti model yang digunakan pada penelitian ini adalah layak. Delapan variabel independen pada penelitian ini yaitu ekspektasi kinerja $\left(X_{1}\right)$, ekspektasi usaha $\left(X_{2}\right)$, faktor sosial $\left(X_{3}\right)$, kondisi yang memfasilitasi $\left(X_{4}\right)$, motivasi hedonisme $\left(X_{5}\right)$, nilai harga $\left(X_{6}\right)$, dan kebiasaan $\left(X_{7}\right)$ mampu memprediksi atau menjelaskan penggunaan $e$ Filing $\left(\mathrm{Y}_{1}\right)$ oleh wajib pajak orang pribadi yang terdaftar di KPP Pratama Tabanan.

Hasil perhitungan statistik pengaruh ekspektasi kinerja pada penggunaan e-Filing menunjukkan nilai $\beta_{1}=-0,067$ dengan tingkat signifikansi $\mathrm{t}$ uji satu sisi variabel ekspektasi kinerja adalah sebesar 0,704 yang lebih besar dari 0,05. Hasil tersebut menunjukkan bahwa $\mathrm{H}_{1}$ ditolak, yang berarti ekspektasi kinerja tidak berpengaruh pada penggunaan e-Filing. Ekspektasi kinerja tidak berpengaruh pada penggunaan e-Filing karena harapan wajib pajak bahwa e-Filing akan membantu penyelesaian SPT lebih cepat masih belum mampu membuat wajib pajak terdorong untuk beralih menggunakan e-Filing. Manfaat yang dirasakan oleh wajib pajak masih belum maksimal. Gangguan yang sering terjadi pada sistem e-Filing membuat beberapa wajib pajak harus datang ke KPP untuk mengurus laporan SPT mereka, sehingga mereka tidak merasakan pelaporan SPT mereka menjadi lebih cepat serta meningkatkan produktivitas dalam pekerjaan. 
Hasil penelitian ini mendukung hasil penelitian sebelumnya yang dilakukan oleh Andriani et al. (2017) yang menyimpulkan bahwa ekspektasi kinerja tidak berpengaruh pada penggunaan e-Filing. Hasil penelitian ini tidak dapat mendukung pernyataan Sutanto et al. (2018) yang menyatakan bahwa ekspektasi kinerja berpengaruh terhadap penggunaan suatu teknologi oleh seorang individu.

Hasil perhitungan statistik dari variabel ekspektasi usaha pada penggunaan $e$-Filing menunjukkan nilai $\beta_{2}=0,313$ dengan tingkat signifikansi $t$ uji satu sisi variabel ekspektasi usaha adalah sebesar 0,016 yang lebih kecil dari 0,05 . Hal tersebut menunjukkan bahwa $\mathrm{H}_{2}$ diterima, yang berarti ekspektasi usaha berpengaruh positif pada penggunaan e-Filing. Harapan wajib pajak dalam kemudahan menggunakan e-Filing untuk melaporkan SPT mampu mendorong wajib pajak untuk menggunakan sistem tersebut. Kesederhanaan sistem membuat pengguna lebih mudah untuk memahami cara penggunaannya, dengan kemudahan penggunaan ini maka kegiatan wajib pajak dalam melaporkan SPT akan lebih efisien dari segi tenaga dan waktu.Hasil penelitian ini sejalan dengan penelitian sebelumnya yang dilakukan oleh Wulandari \& Yadnyana (2016) serta Lu \& Nguyen (2016). Hasil penelitian ini juga sejalan dengan pendapat dari Sutanto et al. (2018) yang menyatakan bahwa kemudahan dalam pengoperasian sistem akan berpengaruh terhadap penggunaan sistem itu sendiri.

Hasil perhitungan statistik dari variabel faktor sosial pada penggunaan $e$ Filing menunjukkan nilai $\beta_{3}=-0,197$ dengan tingkat signifikansi $t$ uji satu sisi variabel faktor sosial adalah sebesar 0,068 yang lebih besar dari 0,05. Hal tersebut menunjukkan bahwa $\mathrm{H}_{3}$ ditolak, yang berarti faktor sosial tidak berpengaruh pada penggunaan e-Filing. Faktor sosial tidak mampu untuk mempengaruhi wajib pajak menggunakan e-Filing karena masih lemahnya kemampuan lingkungan di sekitar wajib pajak untuk membangun keyakinan atau kepercayaan wajib pajak agar menggunakan e-Filing. Berdasarkan hasil jawaban responden, dari empat indikator pernyataan pada variabel faktor sosial pernyataan bahwa staff kantor pelayanan pajak mempengaruhi dalam penggunaan e-Filing memiliki jumlah skor terendah. Hal tersebut berarti bahwa staff pajak masih belum mampu membuat wajib pajak beralih menggunakan $e$ Filing. Kurangnya sosialisasi dari pihak staff pajak terkait dengan penggunaan $e$ Filing dapat menjadi salah satu penyebab kurangnya antusiasme wajib pajak dalam menggunakan e-Filing.Hasil penelitian ini mendukung hasil penelitian dari Khurana \& Jain (2019) bahwa faktor sosial tidak mempengaruhi penggunaan teknologi oleh seorang individu. Hasil penelitian ini tidak dapat mendukung pernyataan Sutanto et al. (2018) yang menyatakan bahwa faktor sosial mempengaruhi penggunaan teknologi informasi.

Hasil perhitungan statistik dari variabel kondisi yang memfasilitasi pada penggunaan $e$-Filing menunjukkan nilai $\beta_{4}=-0,001$ dengan tingkat signifikansi $\mathrm{t}$ uji satu sisi variabel kondisi yang memfasilitasi adalah sebesar 0,997 yang lebih besar dari 0,05. Hal tersebut menunjukkan bahwa $\mathrm{H}_{1}$ ditolak, yang berarti kondisi yang memfasilitasi tidak berpengaruh pada penggunaan e-Filing.Hasil ini disebabkan oleh beberapa wajib pajak yang masih belum memiliki pengetahuan yang diperlukan untuk menggunakan e-Filing. Kesimpulan ini 
didapat dari jumlah skor untuk tingkat pengetahuan e-Filing paling rendah diantara dua pernyataan lainnya. Hasil tersebut mengartikan bahwa belum semua wajib pajak mempunyai pengetahuan yang memadai mengenai cara penggunaan e-Filing. Dalam hal ini, peran staff pajak khususnya bagian help desk sangat penting untuk memberikan informasi yang diperlukan oleh wajib pajak dalam penggunaan e-Filing. Kualitas pelayanan dari help desk dalam memberikan informasi mengenai e-Filing kepada wajib pajak sangat mempengaruhi penggunaan e-Filing itu sendiri.Hasil penelitian ini sejalan dengan penelitian Andriani et al. (2017) yang menyatakan bahwa kondisi yang memfasilitasi tidak berpengaruh terhadap penggunaan e-Filing. Penelitian oleh Ramdhani et al. (2017) juga memperoleh hasil yang sama. Hasil penelitian ini tidak dapat mendukung teori UTAUT 2 yang menyatakan kondisi yang memfasilitasi mempengaruhi penggunaan teknologi oleh individu.

Hasil perhitungan statistik dari variabel motivasi hedonisme pada penggunaan $e$-Filing menunjukkan nilai $\beta_{5}=0,102$ dengan tingkat signifikansi $\mathrm{t}$ uji satu sisi variabel motivasi hedonisme adalah sebesar 0,536 yang lebih besar dari 0,05 . Hal tersebut menunjukkan bahwa $\mathrm{H}_{5}$ ditolak, yang berarti motivasi hedonisme tidak berpengaruh pada penggunaan e-Filing. Hasil penelitian ini menjelaskan bahwa hal-hal seperti kesenangan, prestise dan gengsi dari wajib pajak bukan merupakan faktor pendorong wajib pajak memilih untuk menggunakan e-Filing untuk melaporkan SPT mereka. Ada hal-hal lain yang mampu mendorong wajib pajak untuk menggunakan e-Filing daripada harus datang langsung ke KPP untuk melaporkan SPT mereka seperti kemudahan dalam melapor SPT yang dijelaskan oleh variabel ekspektasi usaha yang berpengaruh signifikan pada penelitian ini.Penelitian ini mendukung hasil penelitian dari Pertiwi \& Ariyanto (2017). Hasil penelitian ini tidak dapat mendukung penelitian Sutanto et al. (2018) yang menyatakan bahwa motivasi hedonisme merupakan faktor terkuat kedua yang mempengaruhi penggunaan suatu teknologi.

Hasil perhitungan statistik dari variabel nilai harga pada penggunaan $e$ Filingmenunjukkan nilai $\beta_{6}=0,406$ dengan tingkat signifikansi $\mathrm{t}$ uji satu sisi variabel nilai harga adalah sebesar 0,005 yang lebih kecil dari 0,05. Hal tersebut menunjukkan bahwa $\mathrm{H}_{6}$ diterima, yang berarti nilai harga berpengaruh positif pada penggunaan e-Filing. Hal tersebut mengartikan bahwa salah satu faktor pendorong wajib pajak lebih memilih menggunakan e-Filing untuk melaporkan kewajiban perpajakannya adalah karena biaya penggunaan e-Filing yang murah. Penggunaan e-Filing hanya memerlukan biaya kuota internet. Terlebih lagi dengan tidak mengenakan tarif harga seperti biaya administrasi, wajib pajak merasa manfaat yang diberikan oleh sistem e-Filing itu sendiri sudah maksimal dan memudahkan pelaporan SPT. Penelitian ini sejalan dengan hasil penelitian dari Putri \& Suardikha (2019) yang menyatakan bahwa nilai harga berpengaruh pada penggunaan teknologi. penelitian ini juga mendukung teori UTAUT 2 bahwa nilai harga berpengaruh pada penggunaan teknologi oleh individu.

Hasil perhitungan statistik dari variabel kebiasaan pada penggunaan $e$ Filing menunjukkan nilai $\beta_{7}=0,335$ dengan tingkat signifikansi $\mathrm{t}$ uji satu sisi variabel kebiasaan adalah sebesar 0,017 yang lebih kecil dari 0,05. Hal tersebut menunjukkan bahwa $\mathrm{H}_{7}$ diterima, yang berarti kebiasaan berpengaruh positif 
pada penggunaan e-Filing. Wajib pajak yang terbiasa melaporkan SPT mereka menggunakan e-Filing akan menggunakannya secara berulang dan terusmenerus karena suatu kebiasaan. Kebiasaan ini membuat mereka berperilau secara otomatis dan menjadi ketagihan (addicted). Terlebih lagi bagi wajib pajak yang memang terbiasa menggunakan suatu sistem teknologi dalam kegiatan sehari-hari, maka hal tersebut akan semakin membuat wajib pajak memilih menggunakan sistem e-Filing karena sudah terbiasa dengan hal-hal yang praktis.Hasil penelitian ini sejalan dengan Putri \& Suardikha (2019), Pertiwi \& Ariyanto (2017), Veeramootoo et al. (2018) yang menyimpulkan bahwa kebiasaan berpengaruh pada penggunaan teknologi. Penelitian ini juga mendukung penelitian dari Sutanto et al. (2018) mengenai teori UTAUT 2 yang menyimpulkan bahwa kebiasaan mempengaruhi penggunaan suatu teknologi.

\section{SIMPULAN}

Ekspektasi kinerja tidak berpengaruh pada penggunaan e-Filing oleh wajib pajak orang pribadi di KPP Pratama Tabanan. Harapan akan adanya kinerja yang lebih cepat dalam melaporkan SPT tidak mempengaruhi penggunaan $e$ Filing oleh wajib pajak. Ekspektasi usaha berpengaruh positif pada penggunaan e-Filing oleh wajib pajak orang pribadi di KPP Pratama Tabanan. Harapan akan adanya kemudahan dalam melaporkan SPT dapat mempengaruhi WPOP untuk menggunakan e-Filing. Faktor sosial tidak berpengaruh pada penggunaan $e$ Filing oleh wajib pajak orang pribadi di KPP Pratama Tabanan. Pengaruh lingkungan di sekitar wajib pajak tidak mampu membangun kepercayaan dan mempengaruhi wajib pajak untuk menggunakan e-Filing.

Kondisi yang memfasilitasi tidak berpengaruh pada penggunaan e-Filing oleh wajib pajak orang pribadi yang terdaftar di KPP Pratama Tabanan. Variabel kondisi yang memfasilitasi tidak mampu membuat wajib pajak beralih menggunakan e-Filing. Motivasi hedonisme tidak berpengaruh pada penggunaan e-Filing oleh wajib pajak orang pribadi di KPP Pratama Tabanan. Hal-hal seperti prestise dan kesenangan tidak mempengaruhi penggunaan $e$ Filing oleh wajib pajak. Nilai harga berpengaruh positif pada penggunaan $e-$ Filing oleh wajib pajak orang pribadi di KPP Pratama Tabanan. Perbandingan antara biaya yang sepadan dengan manfaat yang diperoleh oleh wajib pajak dalam melaporkan SPT mampu membuat wajib pajak beralih menggunakan $e$ Filing. Kebiasaan berpengaruh positif pada penggunaan e-Filing oleh wajib pajak orang pribadi di KPP Pratama Tabanan. Habit atau kebiasaan penggunaan suatu teknologi secara berulang-ulang dapat mempengaruhi wajib pajak menggunakan e-Filing karena terbiasa mengerjakan sesuatu secara praktis.

Hasil kuesioner penelitian menunjukkan dari masing-masing variabel penelitian, terdapat indikator pernyataan yang mendapatkan rata-rata skor terendah. Indikator dari variabel ekspektasi kinerja yang mendapat rata-rata skor terendah adalah indikator pernyataan ketiga, yaitu penggunaan e-Filing meningkatkan produktivitas. Hal tersebut disebabkan karena sering terjadi gangguan pada e-Filing sehingga aktivitas wajib pajak menjadi terhambat. Oleh sebab itu sebaiknya Direktorat Jenderal Pajak terus melakukan pengembangan 
kualitas sistem agar tidak mudah terjadi gangguan server pada saat masa pelaporan SPT.

Indikator dari ekspektasi usaha yang mendapat rata-rata skor terendah adalah pernyataan pertama yaitu interaksi dengan e-Filing mudah dipahami. Dalam hal ini sebaiknya DJP lebih menyederhanakan sistem agar seluruh wajib pajak mampu memahami penggunaan e-Filing. Indikator faktor sosial yang mendapatkan rata-rata skor jawaban terendah adalah pernyataan kedua yaitu staff kantor pelayanan pajak mempengaruhi dalam penggunaan e-Filing. Sebaiknya dalam hal ini staff pajak khususnya bagian help desk lebih aktif lagi untuk memberitahukan wajib pajak tentang penggunaan e-Filing melalui kegiatan sosialisasi.

Indikator kondisi yang memfasilitasi yang mendapatkan rata-rata skor terendah adalah indikator yang kedua yaitu wajib pajak memiliki pengetahuan yang diperlukan untuk penggunaan e-Filing. Dalam hal ini sebaiknya wajib pajak harus lebih aktif lagi mencari tau informasi tentang pelaporan SPT melalui $e$-Filing melalui website DJP maupun dengan bertanya langsung ke KPP Pratama Tabanan.

Indikator motivasi hedonisme yang mendapatkan rata-rata skor jawaban terendah adalah pernyataan yang kedua yaitu penggunaan e-Filing membanggakan. Dalam hal ini sebaiknya pihak fiskus harus lebih memberikan pemahaman melalui sosialisasi kepada wajib pajak mengenai keunggulankeunggulan pelaporan SPT melalui e-Filing daripada datang langsung ke KPP. Indikator dari nilai harga yang mendapat rata-rata skor terendah adalah pernyataan pertama yaitu biaya kuota internet yang dikeluarkan sebanding dengan kemudahan yang didapatkan. Dalam hal ini sebaiknya Pemerintah Daerah Kabupaten Tabanan menyediakan wi-fi gratis pada tempat-tempat umum agar memudahkan masyarakat mengakses internet tanpa kuota internet.

Indikator dari kebiasaan yang mendapat rata-rata skor terendah adalah pernyataan pertama dan kedua yaitu pengguna gemar menggunakan e-Filing dan menggunakan e-Filing memang menjadi keharusan bagi pengguna. Dalam hal ini sebaiknya wajib pajak yang belum pernah menggunakan e-Filing mulai beralih untuk melapor menggunakan e-Filing agar terbiasa dengan penggunaan e-Filing itu sendiri. Keterbatasan dalam penelitian ini adalah pada kuesioner penelitian tidak mencantumkan tingkat pendidikan responden. Tingkat pendidikan merupakan salah satu faktor yang dapat mempengaruhi penggunaan teknologi oleh seseorang. Bagi peneliti selanjutnya diharapkan agar mencantumkan tingkat pendidikan serta hal-hal lain yang mempengaruhi penggunaan teknologi oleh seseorang seperti umur responden pada kuesioner penelitian.

\section{REFERENSI}

Alraja, M. N. (2016). The Effect Of Sosial Influence And Facilitating Conditions On E-Government Acceptance From The Individual Employees' Perspective.Polish Journal of Management Studies, 14(2), 18-27. https:// doi.org/10.17512/ pjms.2016.14.2.02

Andriani, F. D., Napitupulu, T. A., \& Haryaningsih, S. (2017). The Users Acceptance Factors of E-Filling Sistem in Pontianak. Journal of Theoretical and 
Applied Information Technology, 95(17), 1-10.

Annisa, T. O., \& Soewarno, N. (2019). The perception of individual taxpayers against the intention of using e-form services. JEBI, 16(2), 249-255.

Auliya, N. (2018). Penerapan Model Unified Theory Of Acceptance And Use Of Technology 2 Terhadap Minat Dan Perilaku Penggunaan E-Ticket Di Yogyakarta. Jurnal Universitas Islam Indonesia, 1(1), 1-10.

Hadisantoso, E., Awaludddin, I., Anto, L. O., \& Andriani, S. (2019). Effect of Computer Self Efficacy and Easy Use of E-Spt in Reporting Taxes ( Study in Kendari Pratama Tax Service Office ). IOSR Journal of Business and Management (IOSR-JBM), 21(9), 71-83. https://doi.org/10.9790/487X2109047183

Hartono, W. A., \& Meiranto, W. (2015). Pengaruh pemanfaatan dan penggunaan sistem informasi terhadap kinerja individu. Diponegoro Journal of Accounting, 2(4), 1-10.

Khurana, S., \& Jain, D. (2019). Applying and Extending UTAUT 2 Model of Adoption of New Technology in the Context of M-Shopping Fashion Apps. IJITEE, 8(9), 1-20.

Kimea, A., Chimilila, C., \& Sichone, J. (2019). Analysis of Taxpayers' Intention to Use Tax E-Filing System in Tanzania: Controlling for Self-Selection Based Endogeneity. Journal, African Review, Economic Vii, Volume, VII(2), 193-212.

Lu, N. L., \& Nguyen, V. T. (2016). Online Tax Filling: E-Government Service Adoption Case of Vietnam. Lac Hong, 7(1), 1498-1504.

Mangoting, Y., Whitney, G., \& Tjioewinata, G. P. (2019). The Relationships between Technology and User Satisfaction in Online Tax Filing: The Mediating Role of Confirmation of Expectation. Advances in Economics, Business and Management Research, 103(Teams 19), 48-54. https:// doi.org/10.2991/teams-19.2019.8

Mongwaketse, P. B. (2015). Perceived effects of an electronic filing system on tax compliance in a district municipality , South Africa. Research Gate, 1(11), 120. https://doi.org/10.1093/cid/cir749

Nugroho, R. A., Susilowati, A. D., Ambarwati, O. C., \& Pratiwi, A. (2018). Factors Affecting Users ' Acceptance of E-Billing System in Surakarta Tax Office. 9(June), 37-42. https:/ / doi.org/10.21512/comtech.v9i1.4621

Olaoye, C. O., \& Atilola, O. O. (2018). Effect of E-Tax Payment on Revenue Generation in Nigeria. Journal of Accounting, Business and Finance Research, 4(2), 56-65. https:// doi.org/10.20448/2002.42.56.65

Pertiwi, N. W. D. M. Y., \& Ariyanto, D. (2017). Penerapan Model UTAUT 2 Untuk Menjelaskan Minat dan Perilaku Penggunaan Mobile Banking Di Kota Denpasar. 18(2), 1369-1397.

Purnaningsih, N. K. C., \& Noviari, N. (2019). Pengaruh Penerapan e-Filing terhadap Kepatuhan Wajib Pajak Orang Pribadi. E-Jurnal Akuntansi, 28(3), 110.

Putri, N. K. R. D., \& Suardikha, I. M. S. (2019). Penerapan Model UTAUT 2 Untuk Menjelaskan Niat Dan Perilaku Penggunaan E-Money di Kota Denpasar. E-Jurnal Akuntansi, 30(2), 540-555.

Rahman, A., \& Dewantara, R. Y. (2017). Pengaruh Kemudahan Penggunaan Dan Kemanfaatan Teknologi Informasi Terhadap Minat Menggunakan Situs Jual 
Beli Online (Studi Kasus Pada Pengguna Situs Jual Beli "Z"). Jurnal Administrasi Bisnis (JAB), 52(1), 1-7. Retrieved from http:/ / ezproxy.leedsbeckett.ac.uk/login?url=http:/ / search.ebscohost.com/ login.aspx?direct=truedand $b=$ edseurdanAN=edseur..9200111.Bibliographic Resource. 1000086006687 dansite $=$ eds-livedanscope $=$ site

Rakhmawati, H. (2020). Influence of TAM and UTAUT models of the use of efiling on tax compliance. Research Gate, 1(1), 1-20.

Ramdhani, Al Bachri, I. R., \& Prabowo, F. S. A. (2017). Pengaruh Adopsi Teknologi Layanan Uang Elektronik Telkomsel Cash Menggunakan Pendekatan UTAUT 2. E-Proceeding of Management, 4(1), 53-60.

Sichone, J., \& Milano, R. (2017). The Influence of Facilitating Conditions, Perceived Benefits, and Perceived Risk on Intention To Adopt E-Filing in Tanzania. Journals.Udsm.Ac.Tz, 2253(1), 50-59. Retrieved from http://journals.udsm.ac.tz/index.php/bmr/article/view/1152

Sutanto, S., Ghozali, I., \& Handayani, R. S. (2018). Faktor-Faktor Yang Memengaruhi Penerimaan Dan Penggunaan Sistem Informasi Pengelolaan Keuangan Daerah (Sipkd) Dalam Perspektif the Unified Theory of Acceptance and Use of Technology 2 (Utaut 2) Di Kabupaten Semarang. Jurnal Akuntansi Dan Auditing, 15(1), 37. https:// doi.org/10.14710/jaa.15.1.37-68

Syaninditha, S. A. P., \& Setiawan, P. E. (2017). Pengaruh Persepsi Kegunaan, Persepsi Kemudahan, Faktor Sosial, Dan Kondisi Yang Memfasilitasi Terhadap Minat Penggunaan E-Filing. E-Jurnal Akuntansi Universitas Udayana, 21(1), 86-115.

Veeramootoo, N., Nunko, R., \& Dwivedi, Y. K. (2018). What determines success of an e-government service? Validation of anintegrative model of e-filing continuance usage. Government Information Quarterly, 1(1), 1-10.

Wulandari, N. P. A., \& Yadnyana, I. K. (2016). Penerapan Model Unified Theory of Acceptance and Use of Technology di Kota Denpasar. E-Jurnal Akuntansi Universitas Udayana, 14(2), 1270-1297.

Yadnyana, I. K., Wijaya, I. W. K., \& Santanu, G. (2017). Factors Affecting on the Interest in Using E-Filing in East Denpasar, Bali Province, Indonesia. International Journal of Sosial Science and Humanities Research, 5(3), 176-184.

Zaidi, S. K. R. (2017). The moderating effect of culture on e-filing taxes: evidence from India. Journal of Accounting in Emerging Economies, 7(1), 134-152. 